\title{
A Study of Shading Effect on Photovoltaic Modules with Proposed P\&O Checking Algorithm
}

\author{
Rozana Alik ${ }^{1}$, Awang Jusoh ${ }^{2}$, Tole Sutikno ${ }^{3}$ \\ ${ }^{1,2}$ Faculty of Electrical Engineering, Universiti Teknologi Malaysia, 81310 Skudai, Malaysia \\ ${ }^{3}$ Department of Electrical Engineering, Universitas Ahmad Dahlan, Yogyakarta, Indonesia
}

\begin{tabular}{|c|c|}
\hline Article Info & ABSTRACT \\
\hline Article history: & \multirow{9}{*}{$\begin{array}{l}\text { Sun irradiation levels and associated temperature changes are the main } \\
\text { factors that influence the conversion of solar energy into electricity. Most } \\
\text { energy is produced during a hot sunny day as the sun irradiation is at the } \\
\text { maximum level and uniform throughout the solar photovoltaic (PV). } \\
\text { However, most solar PV were frequently get shadowed, completely or } \\
\text { partially, by the neighbouring buildings, trees and passing clouds. } \\
\text { Consequently, the solar PV has lower voltage and current output, hence, } \\
\text { multiple maximum power points (MPP) are existed on the PV curve, which } \\
\text { could cause confusion to the conventional Maximum Power Point Tracker } \\
\text { (MPPT) to track the true MPP for the PV system. Thus, it is important to } \\
\text { examine the impacts of partial shading on the solar PV in order to extract the } \\
\text { maximum possible power. This paper presents a MATLAB-based modelling } \\
\text { for simulation and experimental setup to study the I-V and P-V } \\
\text { characteristics of a solar module under a non-uniform irradiation due to } \\
\text { partial shading condition (PSC). Furthermore, this study is also proposed an } \\
\text { effective method (a variable step size of P\&O with checking algorithm) that } \\
\text { is low cost and higher tracking efficiency. Thus, this study is essential in } \\
\text { improving and evaluating any new MPPT algorithm under the PSC. }\end{array}$} \\
\hline Received Nov 9, 2016 & \\
\hline Revised Jan 15, 2017 & \\
\hline Accepted Jan 29, 2017 & \\
\hline Keyword: & \\
\hline Irradiance & \\
\hline Partial shading & \\
\hline PV system & \\
\hline Solar PV & \\
\hline
\end{tabular}

Copyright () 2017 Institute of Advanced Engineering and Science. All rights reserved.

\section{Corresponding Author:}

Rozana Alik,

Faculty of Electrical Engineering,

Universiti Teknologi Malaysia,

81310 Skunai, Malaysia.

Email: rozana26@live.utm.my

\section{INTRODUCTION}

Most of energy experts believe that more than $50 \%$ of world's electricity in year 2050 are generated by renewable energies and $10 \%$ of it are coming from solar-power technology [1]. The application of solar energy in power generation has attracted the research attention due to its cleanness, efficient, and environmental renewable and sustainable energy resource [2]. It is known that Malaysia was located at the equator of the earth and receive particularly abundant of solar source. An average daily radiation that received by Malaysia is approximately in between $4.21 \mathrm{kWh} / \mathrm{m}^{2}$ to $5.56 \mathrm{kWh} / \mathrm{m}^{2}$. The total installed PV capacity by 2010 was $20493 \mathrm{MW}$ which expected to reach the $23099 \mathrm{MW}$ of maximum-demand capacity in $2020[3]$.

The solar-power technology are increasingly utilized in several applications such as water pumping, electrical vehicles, PV power plants and hybrid systems as well as, military and space applications [4], [5]. However, extracting maximum power from PV array is a challenging task as the output of solar PV is varying according to the temperature and solar insolation [6]. Based on the observation made, the distinction of output power caused by temperature is not obvious compared with the solar PV that been exposed to the different level irradiance. Furthermore, the extraction of maximum output power became harder when 
partially of PV array is shaded due to some part of sun rays are being blocked by dust, cloud, trees and nearby buildings [7-9].

Partial shading is a critical condition in photovoltaic arrays operation. The shaded cells will most likely be driven to operate at reverse-biased voltage as the unshaded cells will force their own current because of receiving lower irradiance compared to the others [10]. Consequently, the shaded cells will produce high resistance which consume more power and reduces the load current. This has caused the cell's temperature to increase, called 'hot spot phenomenon'. This heat might damage the shaded cells under certain conditions. Besides, non-uniform irradiance would cause multiple peak points on the Power-Voltage (PV) characteristics [11].

Maximum power point tracking (MPPT) is one of an effective control method to extract and maintain the maximum available power from the solar PV [11-13]. More than 30 distinct MPPT techniques have been introduced and applied all over the world [14]. Each technique has their own features which differ in terms of complexity, cost, efficiency, sensor used and tracking accuracy especially when the temperature or irradiation varies [15]. Most tracking controller nowadays are using Perturb and Observe (P\&O) as the MPPT algorithm due to its simplicity of implementation and independence to PV array parameters [15-21]. Nevertheless, the conventional P\&O MPPT have two major drawbacks; steady state oscillation due to fixed step size and incapability to track the global MPP during partial shading condition. There were numbers of other methods that also available, for example, Fractional Short Circuit Current (SCC) [22] that envisages the optimal current by using short circuit current and Fractional Open Circuit Voltage (OCV) [23] that estimates the optimal voltage by providing open circuit voltage for the tracking process. Besides, several researchers were suggesting the soft computing methods such as Artificial Neural Network (ANN) [24-26], Fuzzy Logic Control (FLC) [27] and Particle Swarm Optimization (PSO) [28] since most of these techniques were capable in ensuring a good performance in atmospheric conditions. However, the efficiency of these methods were mainly depending on the user's knowledge. The users require to have at least background knowledge about solar PV configuration in order to effectively utilize the optimization technique, especially the PSO method.

Therefore, the significant of this study is to understand the impacts of partial shading on the series connected cells (PV modules) and examine the PV characteristics under partial shading condition. The model was simulated using MATLAB/Simulink simulation model and the study was validated with experimental results of $50 \mathrm{~W}$ commercial module. This paper also presents a variable step size of $\mathrm{P} \& \mathrm{O}$ with checking algorithm to overcome the disadvantages of conventional P\&O MPPT for partially shaded solar PV. This paper is organized as follows: Section 2 presents explanation on the theory of shading effect for PV module. Section 3 elaborates the characteristics of PV model as well as the I-V characteristic under uniform and nonuniform irradiation. The importance and advantages of the proposed algorithm will be explained in Section 4. Section 5 provides the simulation and experimental methodology to explain the shading effect practically. Next, Section 6 presents simulation and experimental results for shading effects on PV module. This Section also presents the simulation results and analysis for PV and load outputs when PV system is connected with variable step size P\&O MPPT and proposed algorithm under partial shading condition. Finally, Section 7 highlights the significant points of this study.

\section{PARTIAL SHADING CONDITION}

It is infrequent to have uniform and constant irradiation all the times in real life. The radiation intensity would be vary and some solar PV could be partially shaded causing less efficiency to the PV system. Figure 1 illustrates an example of module that contain two strings; each string has three solar cells connected in series.

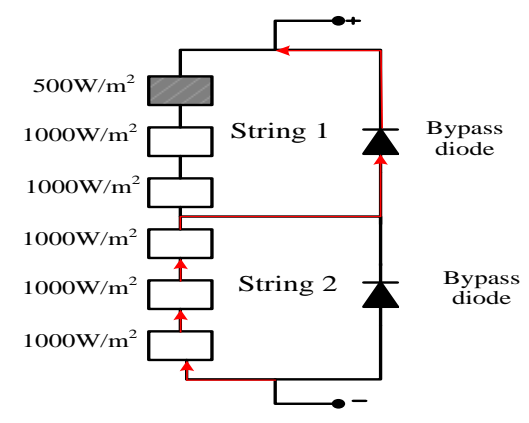

Figure 1. Example of Solar Module Configuration under Partial Shading Condition 
Basically, when one of solar cell in the string is having lesser amount of irradiance, it would produce smaller current compared to the unshaded cells. Since the solar cells are in series connection, every cells should have the same amount of current. Thus, the unshaded cells will impose the shaded cells to yield more current than their short circuit current and causing the shaded cells to operate at a negative voltage. Consequently, a net voltage loss occurred in the system and the shaded cells will act as a load which is absorbing power instead of producing power to the system. As a result, the partially shaded string will become open circuit and the bypass diode will be active to allow the current flow, hence the module would have lower current and power output compare to the other modules that have uniform insolation [4], [6], [8].

As the shaded cells are dissipating power and heat, the temperature of the shaded cells would increase and lead to local heating, thermal stress as well as resulting in total failure to the solar PV [29]. Besides, these phenomenon also caused the characteristic curves to become nonlinear curves and have multiple peak points which will be explained in detail in the next Section [30].

\section{PHOTOVOLTAIC (PV) CHARACTERISTICS}

Photovoltaic (PV) cells can be connected in series or parallel configuration, group as a module and combined to form panels. The panels are connected together to build up the entire PV array [31]. Theoretically, the ideal solar cell can be modelled as current source in anti-parallel with a diode as shown in Figure 2. The direct current would be generated as the cell is been exposed to the light. A shunt resistor and series resistor are included to improve the solar cell model [32].

The PV characteristic equation based on the Figure 2 can be represent as in Equation (1). The equation explains the electrical behaviour and defines the relationship between voltage and current supplied by the PV module [33], [34]:

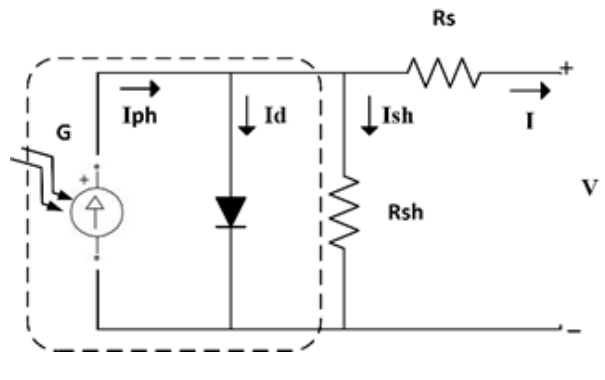

Figure 2. Theoretical circuit for solar cell

$$
I=I_{p h}-I_{s}\left(\exp \left(\left(V+I R_{s}\right) q / a k T N_{s}\right)-1\right)-\left(\left(V+I R_{s}\right) / R_{s h}\right)
$$

where $\mathrm{N}_{\mathrm{s}}=$ number of cells in series, $\mathrm{I}_{\mathrm{ph}}=$ current produced by the photoelectric effect, $\mathrm{I}_{\mathrm{s}}=$ reverse saturation current, $\mathrm{R}_{\mathrm{s}}=$ inherent resistance in series, $\mathrm{R}_{\mathrm{sh}}=$ inherent resistance in parallel, $\mathrm{k}=$ Boltzmann's constant, $\alpha=$ ideality factor modified, $\mathrm{T}=$ cell's temperature

In relation to the assumption, the complete behaviour of solar cell is described by five parameters, $N_{s}, I_{p h}, I_{s}, R_{s}$ and $R_{s h}$. Both $I_{p h}$ and $I_{s}$, which vary based on the environmental conditions (irradiation and temperature) [35]. $\mathrm{I}_{\mathrm{ph}}$ depends on solar irradiation $(\mathrm{G})$ and temperature $(\mathrm{T})$ while $\mathrm{I}_{\mathrm{s}}$ changes based on the temperature $(\mathrm{T})$ as depicted in the equations below,

$$
\begin{aligned}
& I_{p h}=\left[I^{*}{ }_{s c}+k_{i}\left(T-T^{*}\right)\right]^{G} / G^{*} \\
& I_{s}=I^{*}{ }_{s c}+k_{i}\left(T-T^{*}\right) / \exp \left(\frac{V^{*}{ }_{o c}+k_{v}\left(T-T^{*}\right)}{n_{s} v_{t}}\right)-1
\end{aligned}
$$

where $\mathrm{k}_{\mathrm{i}}=$ short circuit current temperature coefficient, $\mathrm{k}_{\mathrm{v}}=$ open circuit voltage temperature coefficient, $\mathrm{I}_{\mathrm{ph}}=$ current produced by the photoelectric effect, $\mathrm{I}_{\mathrm{sc}}=$ short circuit current at standard test condition (STC), 
$\mathrm{V}^{*}{ }_{\mathrm{oc}}=$ open circuit voltage at standard test condition $(\mathrm{STC}), \mathrm{G}^{*}=1000 \mathrm{~W} / \mathrm{m}^{2}, \mathrm{~T}^{*}=$ cell temperature, $\mathrm{v}_{\mathrm{t}}=$ thermal voltage.

In addition, it is compulsory to know the operating voltage and current ( $\mathrm{I}-\mathrm{V}$ and $\mathrm{P}-\mathrm{V}$ curve) for certain states that the solar PV can work in order to control and evaluate the solar cell performance [31]. Figure 3(a) and (b) depict the characteristic curves for I-V and P-V for a given radiation intensity (G) respectively. The module appeared to have varied output power as the irradiation is changing. Besides, it should be noted that the module would has zero current (no load or in vacuum) at the open circuit voltage (Voc) point and zero voltage (short circuit load) at the short circuit current (Isc) point. These characteristic curves would also depend on the cell's temperature as referred to Equation (1). This paper is neglecting the effect of the cell's temperature and has been assumed to be standard temperature, $25^{\circ} \mathrm{C}$. The maximum power point for each curve is different according to various level of irradiation. Hence, it is important to ensure the solar PV to work at this point for the best efficiency.

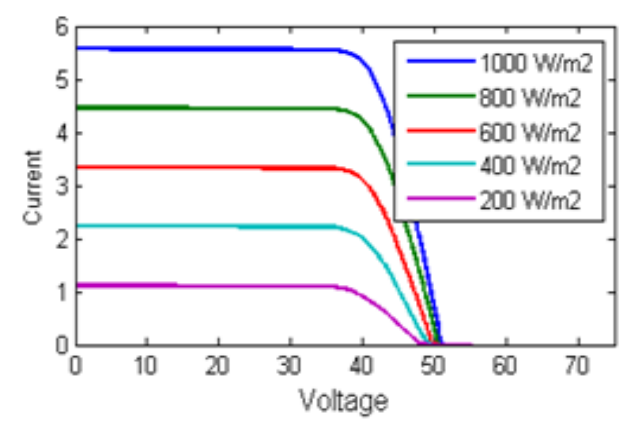

(a)

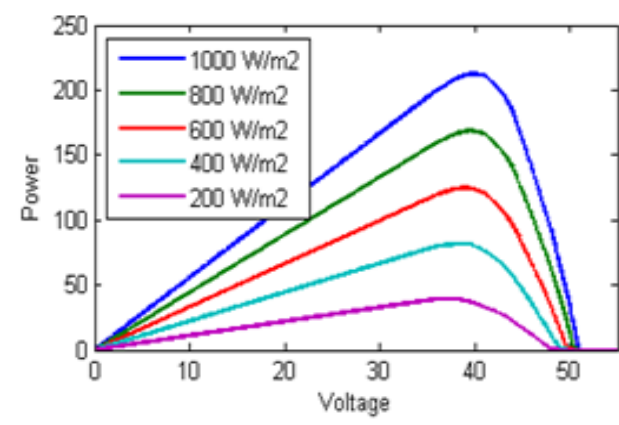

(b)

Figure 3. Characteristic Curves under different Irradiation: (a) I-V Curve, (b) P-V Curve

\section{PROPOSED MPPT ALGORITHM}

Researchers nowadays are trying hard to find solution on overcoming the problems created by partially shaded of solar PV. Thus, it is very important to compare and analyse the existing technique in order to find most suitable and reliable method. Reference [37] proposed a modified P\&O algorithm that used $85 \%$ of the open circuit voltage $\left(\mathrm{V}_{\text {oc }}\right)$ as the voltage reference $\left(\mathrm{V}_{\text {ref }}\right)$ and the perturb voltage $(\Delta \mathrm{V})$ is large enough so that the curve can be scanned faster and easier. The authors managed to reduce the tracking time by $90 \%$ compared to conventional method. Yet, this method has been verified with PV array configuration which suits only for grid connection application.

Meanwhile, reference [38] introduced a perturbative method that used a pair of voltage and current sensors. The simulation results showed the overall efficiency has increased up to above 95\%. Nonetheless, this method requires two sensors to operate which cost more than other method. By using second stage evaluation (checking system) as stated in reference [39], the P\&O method have become more effective and accurate. The experimental results show that the system is capable to find the real MPP in any condition and the system speed performance increases. However, the results show some steady state oscillation problem which lead to lower efficiency. Moreover, reference [15] proposed a fuzzy logic control to create variety step size convergence for the P\&O tracker. As the results, the improve P\&O MPPT has boost up the steady state and performance of the PV system but still unable to track the real MPP when solar PV undergo partial shading condition.

The main idea of this proposed method is combining a variable step size of $\mathrm{P} \& \mathrm{O}$ algorithm [40] and checking algorithm [39]. Figure 4 shows the variable step size of $P \& O$ algorithm where the conventional $\mathrm{P} \& \mathrm{O}$ algorithm is modified to have variable step size instead of constant step size so that the response time would be increase and the oscillation rate at the output side would be lower. As the absolute $\Delta \mathrm{P}$ is lower than 0.001 , indicate that one peak point has been reached and tracked. Yet, it is still unable to track the global MPP which usually get confused and trapped at the local MPP as shown in Figure 5. Therefore, the algorithm need to be modified again in order to ensure the algorithm is tracking the real MPP. 


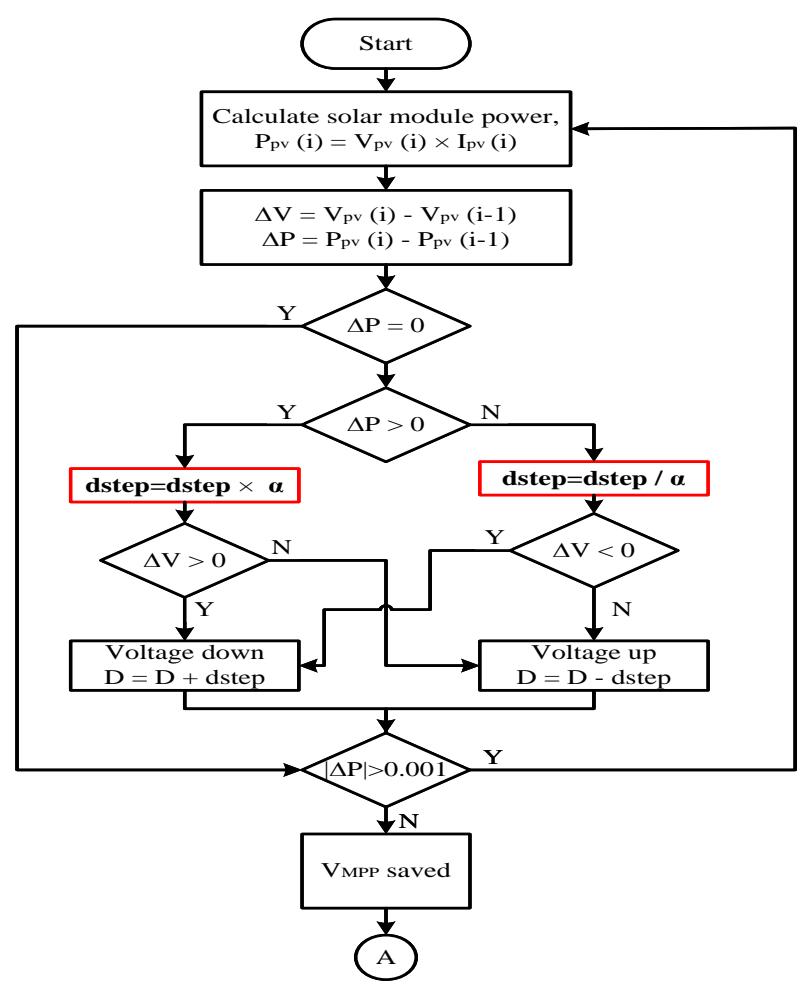

Figure 4. Flow Chart of Variable Step Size of P\&O Algorithm

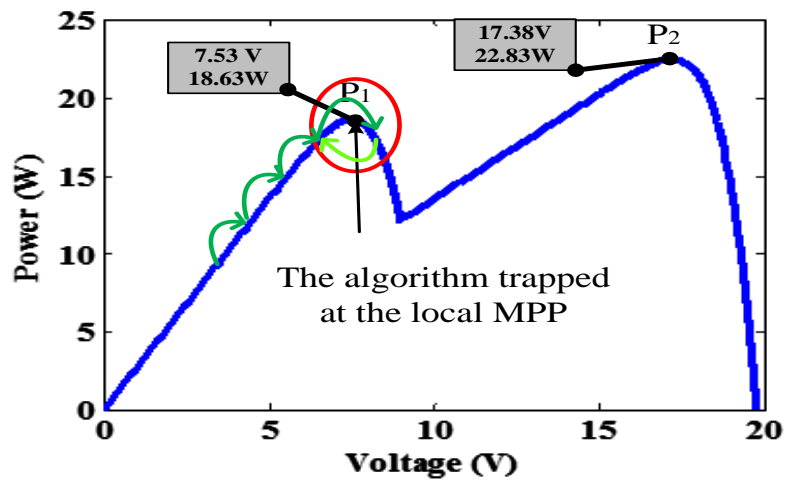

Figure 5. P-V Curve under Partial Shading with Adapted P\&O Algorithm

The checking algorithm (Figure 6) is added after the variable step size of P\&O MPPT to determine whether the saved MMP is the global MPP or only a local MPP. A few concrete operating points need to be measured and compared with the saved MPP. Equation 4 calculates the approximation of minimal distance between MPPs in order to ensure whether it would have to sense to look for another MPP in the surrounding area of the already known operating point.

$$
d_{\min }=V_{\max } / n
$$

where $\mathrm{V}_{\max }=$ nearest voltage to the open circuit voltage, $\mathrm{n}=$ number of bypass diode

The checking algorithm starts with reference voltage, $V_{n}$ set from the lowest possible voltage value, $\mathrm{V}_{\text {min }}$. Thus, another operating point that needs to be measured is the nearest voltage to the short circuit current. Once voltage and current are monitored, the power is calculated and compared with the saved MPP. If it is greater, the voltage will be updated with the reference voltage $\left(\mathrm{V}_{\text {updated }}=\mathrm{V}_{\mathrm{n}}\right)$. Oppositely, a new operating point is calculated, 


$$
V_{n+1}=P_{m p p} / I_{n}
$$

where $\mathrm{P}_{\mathrm{mpp}}=$ maximum power point power obtained by the previous ' $\mathrm{P} \& \mathrm{O}$ subroutine', $\mathrm{I}_{\mathrm{n}}=$ last monitored current.

Next, the new operating point is measured and compared again with the saved MPP value. These steps are repeated to find the highest peak point. In other words, the whole curve will be continuously scanned. The tracking process will be changing abruptly to the possible highest peak point existed as presented in Figure 7. The MPP values would be updated and once again, the variable step size of P\&O algorithm takes place to determine the most accurate value for MPP.

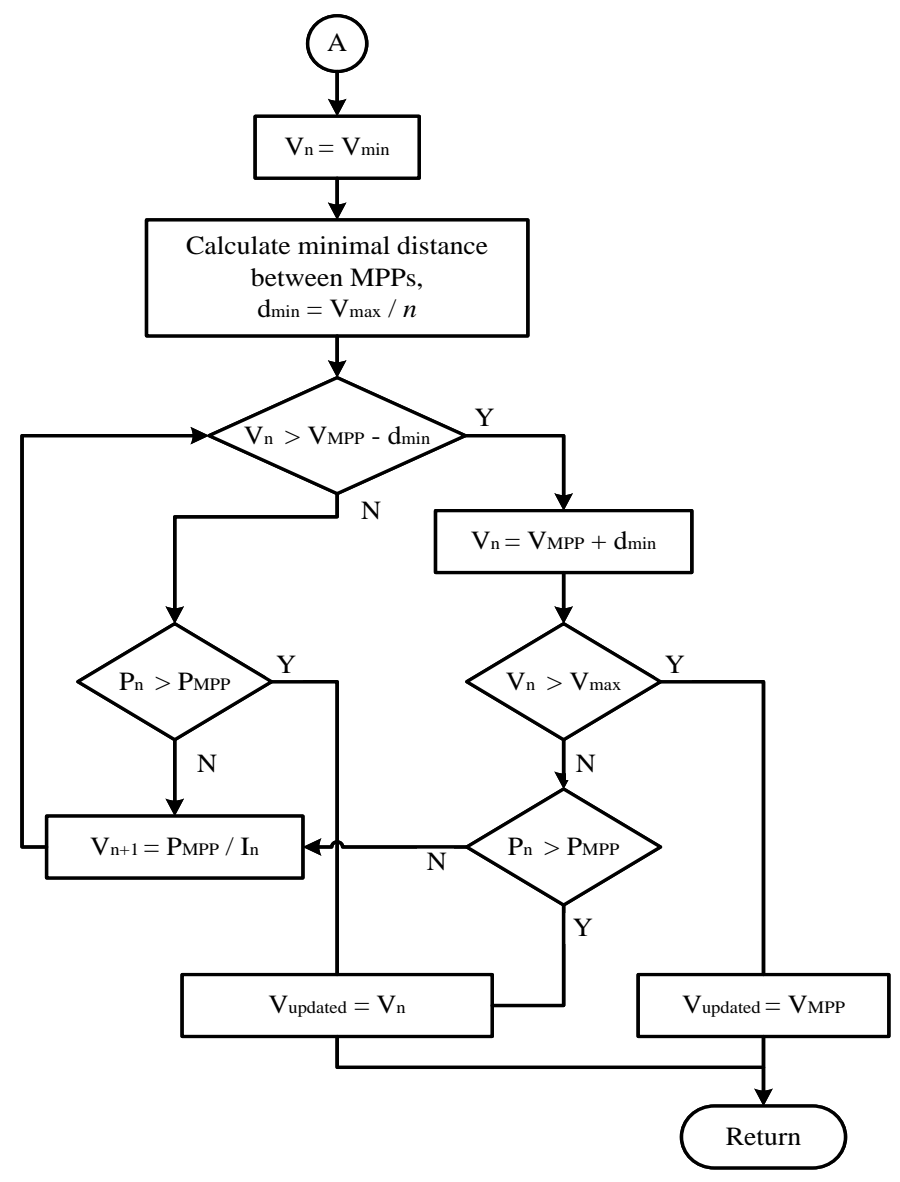

Figure 6. Flow Chart of Variable Step Size of P\&O with Checking Algorithm

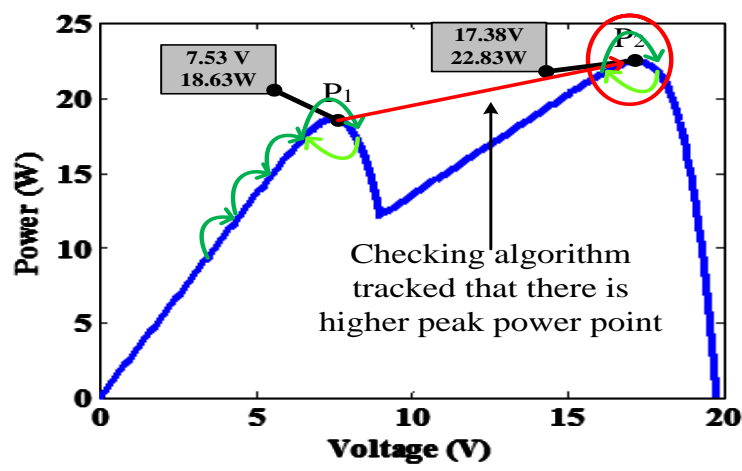

Figure 7. P-V Curve under Partial Shading with Adapted P\&O Algorithm and Checking Algorithm 


\section{SIMULATION AND EXPERIMENTAL PROCEDURE FOR SHADING EFFECT}

To examine the shading effect on the solar modules, a module consists of 36 solar cells seriesconnected is modelled in MATLAB/Simulink as shown in the Figure 8 . Two values of irradiance $\left(1000 \mathrm{~W} / \mathrm{m}^{2}\right.$ and $500 \mathrm{~W} / \mathrm{m}^{2}$ ) are given to the solar module per time to simulate the solar module under partial shading condition.

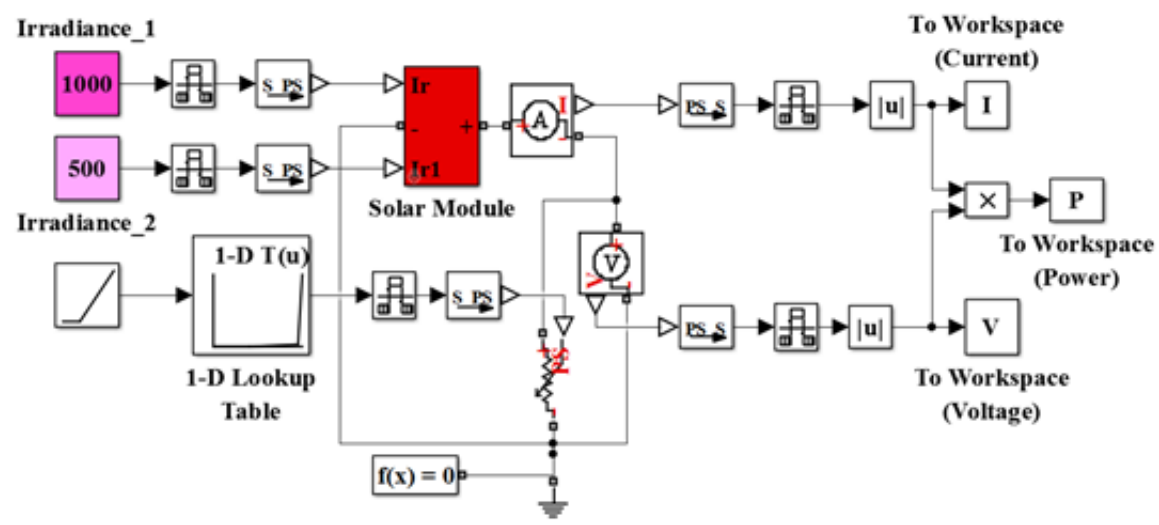

Figure 8. MATLAB/ Simulink Model

The solar module configuration in Figure 9 is modelled by referring the selected PV module used for experimental work which contains 36 solar cells and two bypass diode. The block model of solar cells used in the simulation have been parametrized with five parameters as listed in the Table 1. All parameters except for quality factors and series resistance are set according to the given specifications by the manufactures. The other two parameters are calculated by referring [34] to provide the most suitable value for the solar module. The output current, voltage and power were plotted by using the obtained data in the workspace.
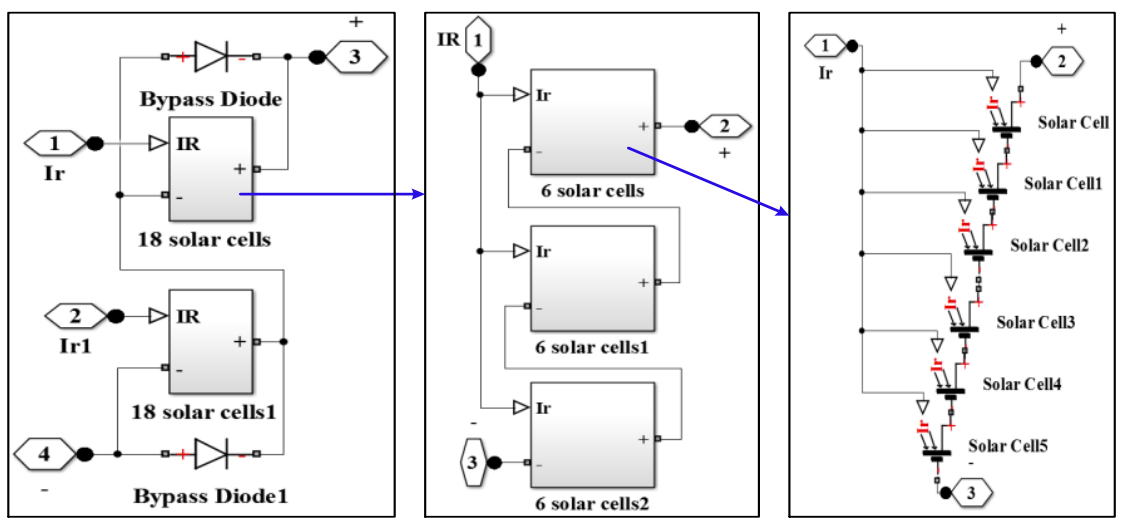

Figure 9. Solar Module Configuration for MATLAB Simulation

Table 1. Parameters Set for 36 Series-Connected Solar Cells

\begin{tabular}{cc}
\hline Parameters & Value \\
\hline Short circuit current, $\mathrm{I}_{\mathrm{sc}}$ & $2.7 \mathrm{~A}$ \\
Open circuit voltage, $\mathrm{V}_{\mathrm{oc}}$ & $0.57 \mathrm{~V}$ \\
Irradiance used for measurements, $\mathrm{Ir}_{0}$ & $1000 \mathrm{~W} / \mathrm{m}^{2}$ \\
Quality factor, $\mathrm{N}$ & 1.3 \\
Series resistance, $\mathrm{R}_{\mathrm{s}}$ & $2.7 \mathrm{e}-3 \Omega$ \\
\hline
\end{tabular}

The simulation results are then validating by an experimental set up as presented in Figure 10 . Table 2 depicts the electrical specifications for the chosen solar module. Three phase variac transformer is used to vary the voltage supply for the halogen bulb. The maximum voltage used is 240V DC supply which

A Study of Shading Effect on Photovoltaic Modules with Proposed P\&O Checking Algorithm (Rozana Alik) 
can contribute for approximately $1000 \mathrm{~W} / \mathrm{m}^{2}$ of irradiance. Therefore, the brightness of halogen bulb (irradiance) is adjusted using potentiometer. In order to have DC voltage supply for the halogen bulb, a three phase rectifier is connected between the variac transformer and the main switch.

The xenon lamps are said to be the most efficient to simulate the solar spectrum but seems to be costly. Alternatively, halogen light bulbs are utilized in this study. The solar simulator shown in the Figure 6 consists of 36 halogen light bulbs $(50 \mathrm{~W} / 240 \mathrm{~V})$. The bulbs were placed right at the top centre of each solar cells. Throughout the experiment, the halogen lamp appears to produce hot light rays and might damage the solar cell. Therefore, an aquarium filled with water is put between the halogen lamp and the solar module [36].

A piece of paper is purposely put onto solar module to have partial shading condition for the system as seen in Figure 11. The voltage and current for each different value of resistor is logged using the digital multimeter. The obtained results were tabulated and plotted as below. The voltage and current for each different value of resistor is logged using the digital multimeter. The obtained results were tabulated and plotted for further analysis.

Table 2. Electrical Specifications

\begin{tabular}{cc}
\hline Peak Power $\left(\mathrm{P}_{\max }\right)$ & $42 \mathrm{~W}$ \\
Maximum Power Point Current $\left(\mathrm{I}_{\mathrm{MPP}}\right)$ & $2.5 \mathrm{~A}$ \\
Maximum Power Point Voltage $\left(\mathrm{V}_{\mathrm{MPP}}\right)$ & $17 \mathrm{~V}$ \\
Short Circuit Current $\left(\mathrm{I}_{\mathrm{SC}}\right)$ & $2.7 \mathrm{~A}$ \\
Open Circuit Voltage $\left(\mathrm{V}_{\mathrm{OC}}\right)$ & $21 \mathrm{~V}$ \\
\hline
\end{tabular}

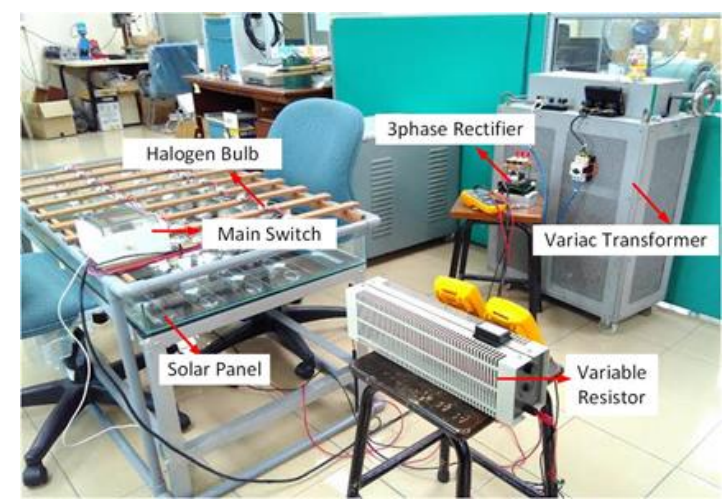

Figure 10. Experimental Set Up

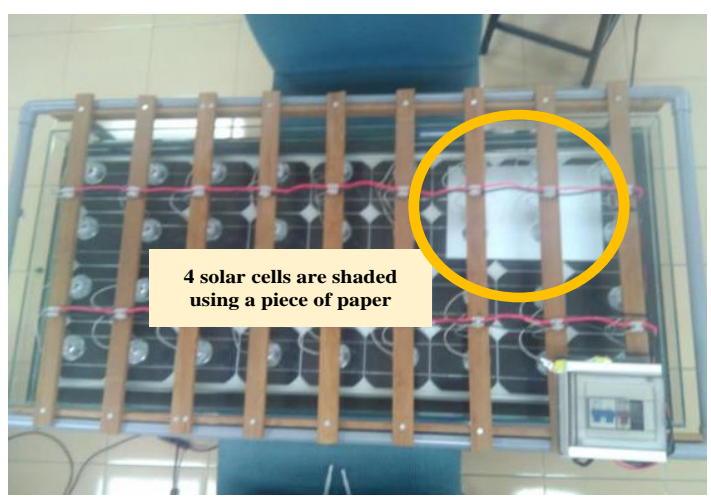

Figure 11. Partially Shaded Solar Module for Experimental Work

\section{RESULT AND ANALYSIS}

\subsection{I-V and P-V Curve Characteristics}

The result for I-V curve and P-V curve under uniform and non-uniform insolation for both simulation and experimental are displayed in Figure 12(a) and (b) respectively. The output current, voltage and power for experimental procedure give lower value than simulation work. This happened because of the temperature of solar module become higher due to some hot light rays produce by the halogen. In addition, the degradation of efficiency of the solar module itself resulting the solar module to have lower output values.

The simulation and experimental results for normal condition exhibit a linear PV characteristics. However, when one of irradiance value is adjusted to $500 \mathrm{~W} / \mathrm{m}^{2}$, it can be seen that the voltage and current produce by the module as well as the output power are changing. The current starts to decrease abruptly when voltage is approaching half of its open circuit voltage, $21 \mathrm{~V}$. The current also seems to be half from the short circuit current, 2.7A. This explains that one of the bypass diode is state of ON and half of solar module is not working due to the partial shading.

During uniform irradiation, there is only one peak point for PV curve in Figure 12, (Simulation: $\mathrm{P}_{\mathrm{MPP}}=41.63 \mathrm{~W}$ and $\mathrm{V}_{\mathrm{MPP}}=16.83 \mathrm{~V}$; Experimental: $\mathrm{P}_{\mathrm{MPP}}=40.67 \mathrm{~W}$ and $\mathrm{V}_{\mathrm{MPP}}=16.4 \mathrm{~V}$ ). There are only slightly difference between simulation and experimental results. Besides, the obtained results for both procedures are nearly same with the given specification, $\mathrm{P}_{\mathrm{MPP}}=42 \mathrm{~W}$ and $\mathrm{V}_{\mathrm{MPP}}=17 \mathrm{~V}$. This shows that the selected solar module still able to work perfectly under normal condition. 
Meanwhile, for partial shading condition, there are multiple peak points $\left(\mathrm{P}_{1}\right.$ and $\left.\mathrm{P}_{2}\right)$ existed on the PV curve (Figure 12). When multiple peak points occurred, one of the point should be the global MPP and the others are the local MPP. Theoretically, the maximum power that should be extracted from the solar PV is the global MPP, for this case, 22.83W. The global maximum power for solar module under partial shading condition appears to be lower than the available maximum power from the solar module that receives uniform and constant irradiation. This clarifies that partially shaded of solar module would never able to produce maximum power as mentioned in the given specification.

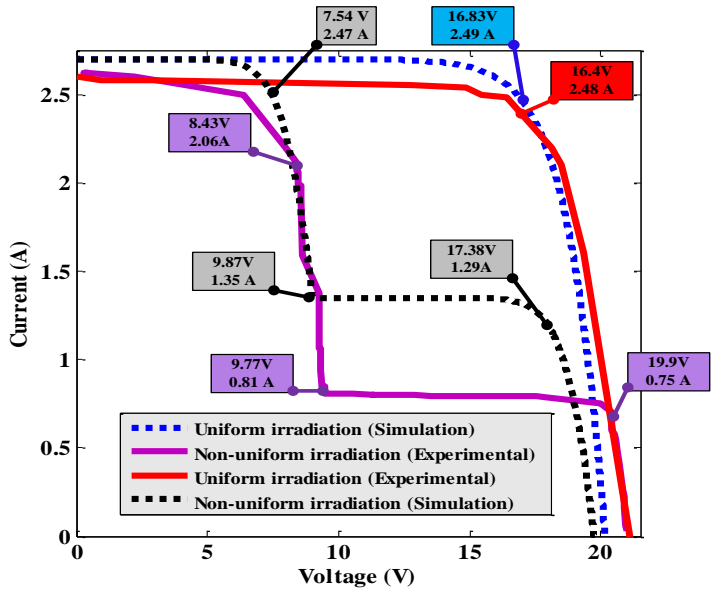

(a)

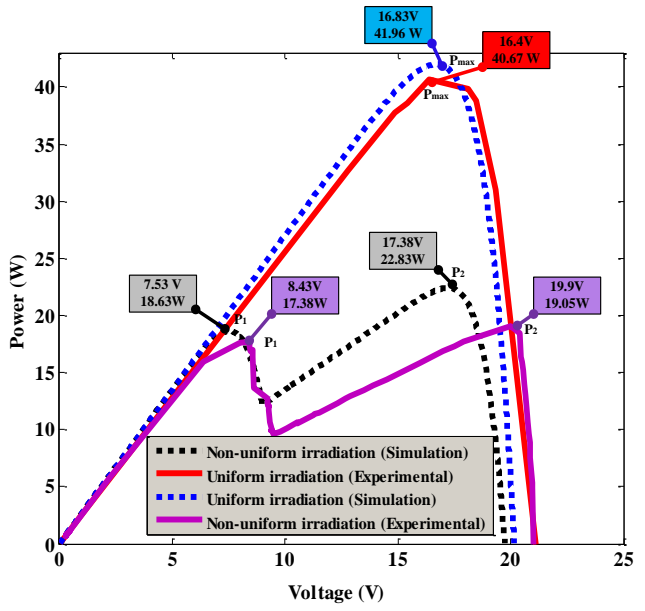

(b)

Figure 12. Simulation and Experimental Results for: (a) I-V Curve, (b) P-V Curve

\subsection{PV Output with Variable Step Size of P\&O MPPT under Partial Shading Condition}

Maximum Power Point Tracking (MPPT) technique is essential in PV system in order to track and extract the available maximum power from the solar PV. It is easier to track the MPP when there was only one peak point existed on the PV curve. This Section would elaborates the effect of having multiple peak points on the PV curve to the variable step size of Perturb and Observe (P\&O) MPPT.
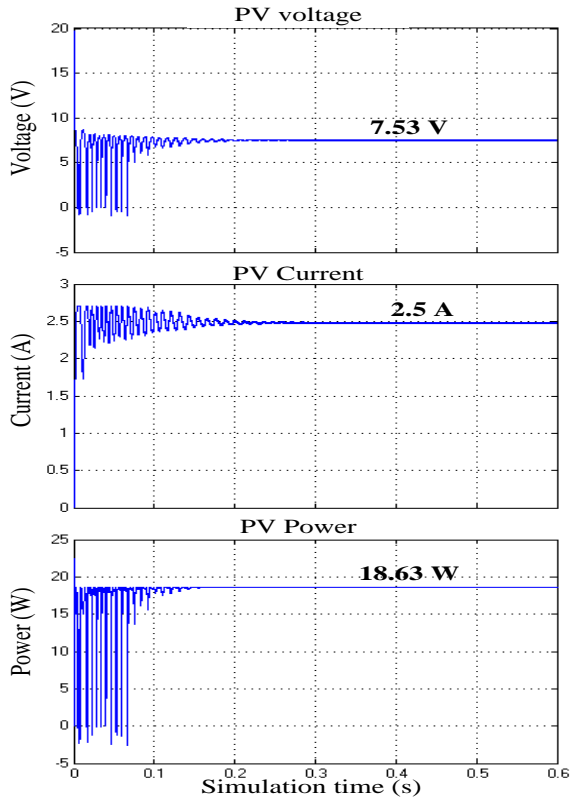
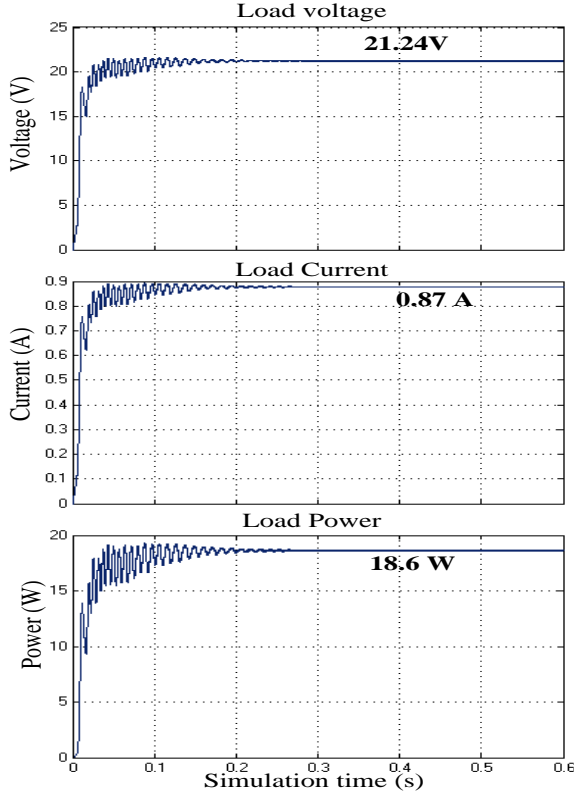

Figure 13. PV and Load Voltage, Current and Power during Partial Shading Condition with Variable Step Size of P\&O MPPT 
Figure 13 displayed the output voltage, current and power for both PV and load respectively. It is proven that even though the oscillation of the outputs on the PV side are low and stable due to the variable step size used but it still unable to track the global MPP. The algorithm is trapped at $\mathrm{P}_{1}$ as expected. The power received by the load for this case is smaller as seen in the Figure 13 which is $18.63 \mathrm{~W}$ and the tracking efficiency is about $81.6 \%$. Nonetheless, the load power is equal to the PV power, indicate the boost converter is worked at its best efficiency.

\subsection{PV Output with Variable Step Size of P\&O MPPT and Checking Algorithm under Partial Shading Condition}

Figure 14 shows the simulation results of output voltage, current and power for both PV and load respectively. It is proven that the proposed algorithm able to track the global MPP. The value of MPPs are changed as soon as the checking algorithm takes place. Besides, the tracking efficiency shows a good results which is $99.8 \%$. Hence, the voltage and current transfer to the boost converter will be much higher and has achieved the required voltage, $40 \mathrm{~V}$. The boost converter appears to work at the best efficiency as the load power is equal to the PV power as seen in the figure.
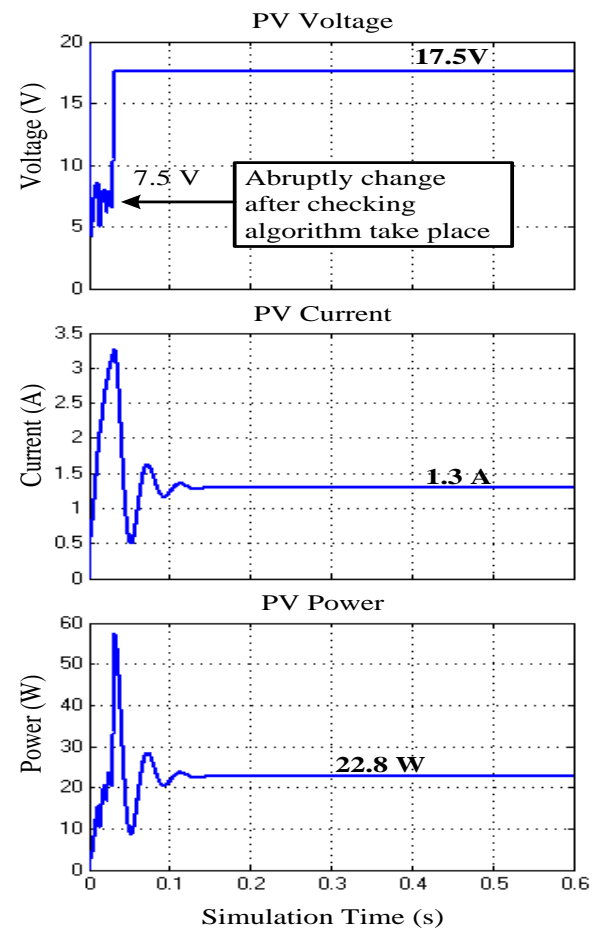
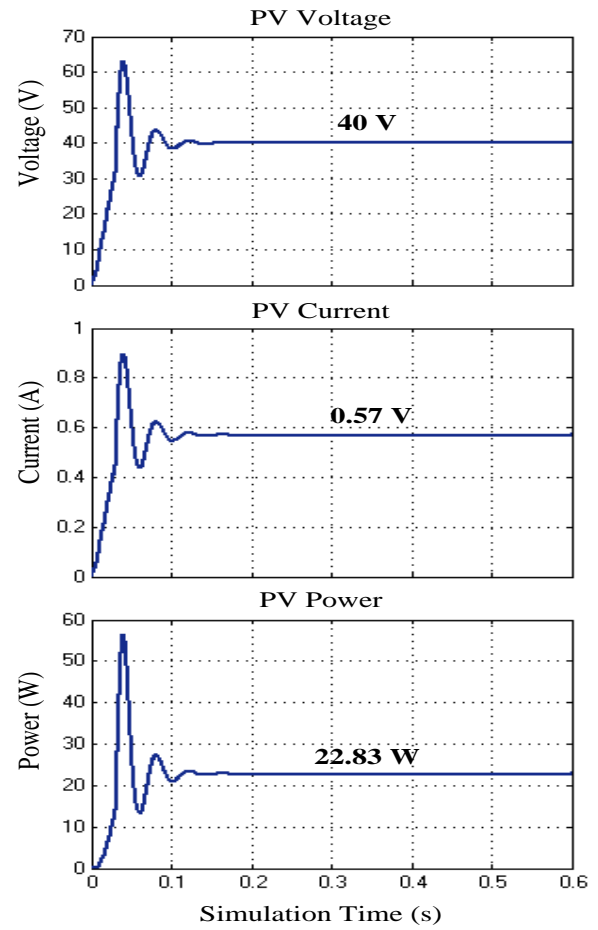

Figure 14. PV and Load Voltage, Current and Power during Partial Shading Condition with Proposed Checking Algorithm

\section{CONCLUSION}

In this paper, a detailed discussion on the impacts of shading to the PV module based on the results obtained from simulation using MATLAB/Simulink and experimental set up are presented. The simulation and experimental results had shown that if the solar module is receiving constant irradiation, maximum power can be yield. On the other hand, only $20 \%$ to $50 \%$ of power be able to be extracted from partially shaded of solar module.

This research paper also elaborates the drawbacks of having only a variable step size of Perturb and Observe (P\&O) MPPT without checking algorithm for a solar PV under partial shading condition. The proposed checking algorithm has proven that it able to track the global MPP under partial shading condition.

In short, it is important to consider the best location to put the solar PV (away from being blocked by any buildings or trees) in order to prevent the shading effects. Besides, the PV system must have an effective MPPT method to ensure the best performance of the solar PV as constant irradiation is rarely happen in real life. 


\section{ACKNOWLEDGEMENTS}

The authors would like to thank Ministry of Education of Malaysia (MOE) and Universiti Teknologi Malaysia (UTM) for providing Research University Grant (RUG) under vote number Q.J130000.2523.07H82 for this research work.

\section{REFERENCES}

[1] M. Z. A. Ab Kadir, et al., "Prospective scenarios for the full solar energy development in Malaysia," Renewable and Sustainable Energy Reviews, vol/issue: 14(9), pp. 3023-3031, 2010.

[2] R. Clift, "Climate change and energy policy: the importance of sustainability arguments," Energy, vol/issue: 32(4), pp. 262-268, 2007.

[3] K. Solangi, et al., "Development of solar energy and present policies in Malaysia," in Clean Energy and Technology (CET), 2011 IEEE First Conference on., 2011.

[4] M. Abdulazeez and I. Iskender, "Simulation and experimental study of shading effect on series and parallel connected photovoltaic PV modules," in Electrical and Electronics Engineering (ELECO), 2011 7th International Conference on., 2011.

[5] M. A. Green, "Solar cells: operating principles, technology, and system applications," 1982.

[6] A. S. Masoum, et al., "Impact of partial shading on voltage-and current-based maximum power point tracking of solar modules," in IEEE PES General Meeting, 2010.

[7] E. L. Meyer and E. E. van Dyk, "Assessing the reliability and degradation of photovoltaic module performance parameters," IEEE Transactions on Reliability, vol/issue: 53(1), pp. 83-92, 2004.

[8] H. Patel and V. Agarwal, "MATLAB-based modeling to study the effects of partial shading on PV array characteristics," IEEE transactions on energy conversion, vol/issue: 23(1), pp. 302-310, 2008.

[9] M. Seyedmahmoudian, et al., "Simulation and hardware implementation of new maximum power point tracking technique for partially shaded pv system using hybrid depso method," IEEE Transactions on Sustainable Energy, vol/issue: 6(3), pp. 850-862, 2015.

[10] R. Ramabadran and B. Mathur, "Matlab based modelling and performance study of series connected SPVA under partial shaded conditions," Journal of Sustainable development, vol/issue: 2(3), pp. 85, 2009.

[11] I. Houssamo, et al., "Maximum power tracking for photovoltaic power system: Development and experimental comparison of two algorithms," Renewable Energy, vol/issue: 35(10), pp. 2381-2387, 2010.

[12] S. Y. Tseng and H. Y. Wang, "A photovoltaic power system using a high step-up converter for DC load applications," Energies, vol/issue: 6(2), pp. 1068-1100, 2013.

[13] C. C. Chu and C. L. Chen, "Robust maximum power point tracking method for photovoltaic cells: A sliding mode control approach," Solar Energy, vol/issue: 83(8), pp. 1370-1378, 2009.

[14] A. P. Bhatnagar and B. Nema, "Conventional and global maximum power point tracking techniques in photovoltaic applications: A review," Journal of Renewable and Sustainable Energy, vol/issue: 5(3), pp. 032701, 2013.

[15] F. Aashoor and F. Robinson, "A variable step size perturb and observe algorithm for photovoltaic maximum power point tracking," in 2012 47th International Universities Power Engineering Conference (UPEC), 2012.

[16] L. Piegari and R. Rizzo, "Adaptive perturb and observe algorithm for photovoltaic maximum power point tracking," IET Renewable Power Generation, vol/issue: 4(4), pp. 317-328, 2010.

[17] K. Nanshikar and A. Desai, "Simulation of P \& O Algorithm using Boost Converter."

[18] M. Killi and S. Samanta, "Modified perturb and observe MPPT algorithm for drift avoidance in photovoltaic systems," IEEE Transactions On Industrial Electronics, vol/issue: 62(9), pp. 5549-5559, 2015.

[19] N. Femia, et al., "Optimization of perturb and observe maximum power point tracking method," IEEE transactions on power electronics, vol/issue: 20(4), pp. 963-973, 2005.

[20] M. Alqarni and M. K. Darwish, "Maximum power point tracking for photovoltaic system: modified perturb and observe algorithm," in 2012 47th International Universities Power Engineering Conference (UPEC), 2012.

[21] H. Rezk and A. M. Eltamaly, "A comprehensive comparison of different MPPT techniques for photovoltaic systems," Solar Energy, vol. 112, pp. 1-11, 2015.

[22] T. Noguchi, et al., "Short-current pulse-based maximum-power-point tracking method for multiple photovoltaicand-converter module system," IEEE Transactions on Industrial Electronics, vol/issue: 49(1), pp. 217-223, 2002.

[23] M. A. Masoum, et al., "Theoretical and experimental analyses of photovoltaic systems with voltageand currentbased maximum power-point tracking," IEEE Transactions on Energy Conversion, vol/issue: 17(4), pp. 514-522, 2002.

[24] M. Karamirad, et al., "ANN based simulation and experimental verification of analytical four-and five-parameters models of PV modules," Simulation Modelling Practice and Theory, vol. 34, pp. 86-98, 2013.

[25] A. K. Rai, et al., "Simulation model of ANN based maximum power point tracking controller for solar PV system," Solar Energy Materials and Solar Cells, vol/issue: 95(2), pp. 773-778, 2011.

[26] M. Kaliamoorthy, et al., "Solar powered single stage boost inverter with ANN based MPPT algorithm," in Communication Control and Computing Technologies (ICCCCT), 2010 IEEE International Conference on., 2010.

[27] Y. T. Chen, et al., "A fuzzy-logic based auto-scaling variable step-size MPPT method for PV systems," Solar Energy, vol. 126, pp. 53-63, 2016.

[28] M. Miyatake, et al., "Maximum power point tracking of multiple photovoltaic arrays: a PSO approach," IEEE Transactions on Aerospace and Electronic Systems, vol/issue: 47(1), pp. 367-380, 2011. 
[29] L. Fialho, et al., "Effect of shading on series solar modules: simulation and experimental results," Procedia Technology, vol. 17, pp. 295-302, 2014.

[30] R. Alik, et al., "An improved perturb and observe checking algorithm MPPT for photovoltaic system under partial shading condition," in 2015 IEEE Conference on Energy Conversion (CENCON), 2015.

[31] B. Bendib, et al., "A survey of the most used MPPT methods: Conventional and advanced algorithms applied for photovoltaic systems," Renewable and Sustainable Energy Reviews, vol. 45, pp. 637-648, 2015.

[32] J. R. Hernanz, et al., "Two photovoltaic cell simulation models in Matlab/Simulink," International Journal on Technical and Physical Problems of Engineering (IJTPE), vol/issue: 4(1), pp. 45-51, 2012.

[33] S. Nema, et al., "MATLAB/Simulink based study of photovoltaic cells/modules/array and their experimental verification," International journal of Energy and Environment, vol/issue: 1(3), pp. 487-500, 2010.

[34] K. Ishaque, et al., "Modeling and simulation of photovoltaic (PV) system during partial shading based on a twodiode model," Simulation Modelling Practice and Theory, vol/issue: 19(7), pp. 1613-1626, 2011.

[35] A. Chouder, et al., "Modeling and simulation of a grid connected PV system based on the evaluation of main PV module parameters," Simulation Modelling Practice and Theory, vol/issue: 20(1), pp. 46-58, 2012.

[36] E. Cuce, et al., "An experimental analysis of illumination intensity and temperature dependency of photovoltaic cell parameters," Applied Energy, vol. 111, pp. 374-382, 2013.

[37] H. Patel and V. Agarwal, "Maximum power point tracking scheme for PV systems operating under partially shaded conditions," IEEE transactions on industrial electronics, vol/issue: 55(4), pp. 1689-1698, 2008.

[38] Y. S. Kumar and R. Gupta, "Maximum power point tracking of multiple photovoltaic arrays," in Engineering and Systems (SCES), 2012 Students Conference on., 2012.

[39] R. Alonso, et al., "An innovative perturb, observe and check algorithm for partially shaded PV systems," in Power Electronics and Applications, 2009. EPE'09. 13th European Conference on., 2009.

[40] A. B. Jusoh, et al., "Variable step size Perturb and observe MPPT for PV solar applications," TELKOMNIKA (Telecommunication Computing Electronics and Control), vol/issue: 13(1), pp. 1-12, 2015. 